Original Research Paper

\title{
Comparability Assessment of Polycyclic Aromatic Hydrocarbons Tissue Load in Some Fish: Implication on Reciprocal Synergism and Risk Assessment
}

\author{
${ }^{1}$ Victor Eshu Okpashi, ${ }^{2}$ Ogugua Victor Nwadiogbu, ${ }^{3}$ Joshua Parkar Elijah, \\ ${ }^{4}$ Chibuike Samuel Ubani, ${ }^{5}$ Obinna Aru Oje, ${ }^{6}$ David Mbu Akpo, \\ ${ }^{7}$ Robert Ikechukwu Uroko and ${ }^{4}$ Ikechukwu Noel Onwurah \\ ${ }^{l}$ Environmental Toxicology and Molecular Biochemistry Unit, University of Nigeria, Nsukka, Nigeria \\ ${ }^{2}$ Department of Biochemistry, University of Nigeria, Nsukka, Nigeria \\ ${ }^{3}$ Pharmacology Unit, Department of Biochemistry, University of Nigeria, Nsukka, Nigeria \\ ${ }^{4}$ Industrial Biochemistry and Biotechnology Unit, Department of Biochemistry, University of Nigeria, Nsukka, Nigeria \\ ${ }^{5}$ Department of Chemistry/Biochemistry/Molecular Biology, Federal University Ebonyi State, Nigeria \\ ${ }^{6}$ Department of Environmental Education, University of Calabar, Nigeria \\ ${ }^{7}$ Department of Biochemistry, College of Natural Science, Michael Okpara University of Agriculture, Umudike, Nigeria
}

Article history

Received: 08-08-2016

Revised: 21-12-2016

Accepted: 08-04-2017

Corresponding Author:

Victor Eshu Okpashi

Environmental Toxicology and Molecular Biochemistry Unit,

University of Nigeria, Nsukka, Nigeria

Email: vic2reshu@gmail.com

\begin{abstract}
Six years after oil spill occur in Qua Ibeo river, environmental monitoring was set out to investigate residual petroleum compounds (PHCs) that are bio-accumulated by fish. Bio-concentration of residual Polycyclic Aromatic Hydrocarbons (PAHs) in fish tissues was determined in six fresh fish species. Twelve water samples were collected from Qua Ibeo river $1 \mathrm{KM}$ apart. The screening was conducted using Agilent gas chromatography tandem mass spectroscopy. Results revealed 17 PAHs accumulated at variable concentrations. Bio-concentration factor and free PAHs in water was calculated by finding the ratio of PAHs concentration in fish tissue to water free PAHs concentration. The contaminant body load was extrapolated by summation of individual PAHs concentration. Results shows African Red snipper (Lutjanus agennes) 20.822 \pm 0.6132 with body load as the highest, Yellow tail (Seriola lalandi) 13.111 \pm 1.247 , Atlantic Crocker (Micropogonias undulates) 9.8439 \pm 6.569 , Tilpia (Oreochromis niloticus) 9.7790 \pm 12.305 , Cat Fish (Clarias gariepinus) $7.298 \pm 4.529$ and Barracuda (Sphyraena barracuda) $6.853 \pm 7.937$ respectively. The percentage PAHs concentration in samples was also determined, for instance, African red snapper have 10.9\% Indeno $(1,2,3, \mathrm{~cd})$ pyrene, Yellow tail 10.94\% Benzo (a) pyrene, Barracuda $10.05 \%$ Indeno $(1,2,3, \mathrm{~cd})$ pyrene, Atlantic Croker $13.03 \%$ Indeno $(1,2,3, \mathrm{~cd})$ pyrene, Catfish $9.61 \%$ Indeno $(1,2,3, \mathrm{~cd})$ pyrene and Tilapia (Oreochromis niloticus) $11.84 \%$ Indeno $(1,2,3, \mathrm{~cd})$ pyrene respectively.
\end{abstract}

Keywords: Bio-Concentration Factor, PAHs Body Load, Risk Assessment, Public Health and Environmental Monitoring

\section{Introduction}

Many names have been used to link patients syndromes associated with sensitivity to pollutants. The difficulty in achieving scientific investigations that will agree with definition of such situation has not received a breakthrough (Rose et al., 2012). Contaminants body burden is organism's overall contaminant concentration, usually from air, food and water or surroundings (NRC, 1992). The organism must match with this burden. Though, there are usually expelled or put into restrictive section. This research monitored the environmental risk. The knowledge is derived from previous research works on environmental risk limits of petroleum aromatic hydrocarbons. The risk limits are calculated by concentration of substances in the organisms when they
Science

Publications
(C) 2017 Victor Eshu Okpashi, Ogugua Victor Nwadiogbu, Joshua Parkar Elijah, Chibuike Samuel Ubani, Obinna Aru Oje, David Mbu Akpo, Robert Ikechukwu Uroko and Ikechukwu Noel Onwurah. This open access article is distributed under a Creative Commons Attribution (CC-BY) 3.0 license. 
might have taken in the pollutant from media. The concept of contaminants body load bear testimony to the organisms multiple sensitivity to environmental contaminants due to reciprocal synergism (NRC, 1991). A patient or an organism with multiple chemical sensitivities or synergetic contaminants effect may be identify by separating the queer offending agent and challenging after reasonable interval, under controlled conditions (Rose et al., 2012). Causation can be deduced by elimination of signs, removal from the hurting media and recurrence of signs with distinct contest. Petroleum hydrocarbons compounds are released into the environment media through accidents discharge of industrial effluent. Contaminants are also released into water by oil thieves and desperate crude oil vandals. Whenever pollutants such as PAHs are released directly into water column by spills or leaks, PAHs fractions will float in water and form thick surface films. Some heavier fractions of the PAHs will accumulate in the sediment, where benthic organisms may be affected. The case of oil spills in Eket has been reported, for example the Ibeno spill that occurred on May 1st, 2010, where a burst Exxon Mobil pipeline leaked over a million gallons crude oil into the coast in about seven days before the leakage was stopped and within days of the spill, thick balls of tar were calcified along the coast. After the Exxon Mobil incident, another crude oil spill occur at Ibeno, where several barrels of oil were leaked due to Vandals attack on the Shell Trans Niger pipeline (DeWitt et al., 1992). In 2012, over 200,000 barrels of crude oil leaked into the coastal communities of Eket. Similarly, some incidence of oil spill were reported to have occur at the Qua Iboe oil fields on August 13, 24, November 9, December 16 and 19, 2012 respectively. (Gobas et al., 1999) Study on PAHs shows that oil spills and gas flaring are a major route for introducing PAHs into the environment and aquatic ecosystems can be stressed. The health risk and yearly economic loss to the inhabitants due to these activities cannot be quantified. The water and sediment qualities within the study area are also influenced by sewage, indiscriminate disposal of solid waste, trading activities, abattoir (slaughter houses) and run-off from agricultural lands. PAHs are organic compounds with two or more benzene rings. Their existence results from incomplete burning of smoke materials. Therefore, PAHs are constituents and derivatives of petroleum (Atuanya and Nwogu, 2013). Spillage of oils and effluents from refineries contributory sources of PAHs pollution on aquatic ecosystem. The impact is weigh on human who live by consuming both the polluted water and contaminated fishes. The resultant effect is the hormonal alteration. Therefore, methods for estimating concentration of specific contaminants, developing accurate estimation of tissue concentrations of PAHs in aquatic organisms, monitor existing bioaccumulation in order to predict bioaccumulation due to future exposure and the use of aquatic organisms as biomarkers for precise prediction of compounds and assessment of contaminants synergetic impact and effect on aquatic organisms, gave impetus to of this investigation.

\section{Materials and Methods}

\section{Sampling Locations}

Four different locations were marked in order to collect twelve samples. The locations were established on ecological settings and anthropogenic activities. The locations were $1 \mathrm{~km}$ apart. Between location 1 and 4 , a total of $3 \mathrm{~km}$ was covered.

\section{Location 1}

The sampling location was the upstream, located at Ikot Ikpe and Ikot Akpoenang at latitude 40 55.8" and longitude 70 40.8". Anthropogenic activities in this location include fishing and boat making at the edge of the river. The water is considerably clean by human eye-sight evaluation.

\section{Location 2}

Location 2 is influenced with effluents from the meat factory along Ikot Aroku and Ikot Naidiba Village Road. Household from residential houses are also discharged into the River. The main activities are mining and loading of sand for commercial purposes. It is about $1 \mathrm{~km}$ away from station 1 and located at latitude 40 22.9" and longitude 70 13.8".

\section{Location 3}

Location 3 was along Eket-Etinan Road, around Ebiyan and Ndon and visibly opposite Onna Local Government Area. Actions here include automobile washing, clothes and bathing. The vegetation is dominated with green bamboo strands. It is $1 \mathrm{~km}$ apart from point 2.

\section{Location 4}

Location 4 was Ndilla, across the river are Odio and Ale Ebukuku, which derived into Ibeno local government area. The activities are mining of sand. This area is turbid due to sufficient discharge of solid wastes. It is very deep due to the sand mining activities.

\section{Collection of River Water Sample}

Water samples were collected with 12 amber bottles, each $100 \mathrm{~mL}$ at twelve locations on 2nd September, 2015 between 10 a.m to 3 p.m. The collected samples were extracted using normal hexane before the concentration of analytes within $30 \mathrm{~min}$. 


\section{Reagents and Chemicals}

All chemicals were of analytical grade and were products of British Drug House (BDH) Chemical limited, Poole England.

\section{Collection of Fish Sample}

The fish were collected randomly. Some variables influenced the site selection they include proximity to oil wells locations, gas flaring from Bonny Bright, heightened population and socio-economic activities.

Locally consumed fresh fish were used. They include: African red snipper (Lutjanus agennes), yellow tail (Seriola lalandi), atlantic crocker (Micropogonias undulates), tilpia (Oreochromis niloticus), cat fish (Clarias gariepinus) and barracuda (Sphyraena barracuda) respectively. They were collected by a resident fisherman using set nets.

\section{Preparation, Extraction and Clean-Up Procedure of Fish Samples for Analysis}

Before the extraction of fish samples, scales were removed and dissected using knife. A $15 \mathrm{~g}$ of the fish tissue was pounded in a clean mortar with pestle in addition to $40 \mathrm{~g}$ of anhydrous sodium sulphate until homogenized. Dichloromethane solvent was used for sample extraction. A $10 \mathrm{~g}$ of the homogenized sample was placed in $50 \mathrm{~mL}$ of extraction bottle and $1 \mathrm{~mL}$ of $60 \mathrm{ng} / \mathrm{mL}$ of 1 - chloro-octadecane surrogate standard was added in the extraction bottle. The content was agitated for $5 \mathrm{~h}$ and allowed for $1 \mathrm{~h}$ to settle. The homogenates was carefully filtered through a funnel fitted with cotton wool, silica gel and sodium sulphate $\left(\mathrm{Na}_{2} \mathrm{SO}_{4}\right)$ in a volumetric flask. The residue was washed and the volume made up using the extraction solvent. The sample was concentrated to $2 \mathrm{~mL}$ for PAHs analysis using a gas chromatography tandem mass spectroscopy.

\section{Method of GC-MS}

Gas chromatographic tandem mass spectroscopy technique was used with the following conditions. GC/MS-QP2010 Agilent Plus, ion source temperature: $200.00^{\circ} \mathrm{C}$, interface temperature: $250.00^{\circ} \mathrm{C}$, solvent cut time: $2.50 \mathrm{~min}$, detector gain mode: $\mathrm{MS}$, detector gain: $0.00 \mathrm{kV}$, threshold: 2000, column oven initial temperature: $70.0^{\circ} \mathrm{C}$, injection final temperature: $250.00^{\circ} \mathrm{C}$, injection Mode: Split, flow control mode: linear velocity, pressure: $116.9 \mathrm{kPa}$, total Flow: $40.8 \mathrm{~mL} \mathrm{~min}^{-1}$, column flow: $1.80 \mathrm{~mL} \mathrm{~min}^{-1}$, linear velocity: $49.2 \mathrm{~cm}$ $\mathrm{sec}^{-1}$, trap and purge flow: $3.0 \mathrm{~mL} \mathrm{~min}^{-1}$, Split Ratio: 20.0 , high pressure injection: OFF, Carrier Gas: Helium and Splitter hold: OFF. While oven rating was as follows: Oven Temp. Program Rate Temperature $\left({ }^{\circ} \mathrm{C}\right)$ Hold Time (min) Initial: 0.00 70.0 0.00 Final: 10.0 280 5.00.

\section{Extraction of Water Samples for PAH Quantification}

Liquid-liquid extraction protocol was used. A litre of sample was extracted in a 2 litre glass separating funnel fitted with a glass stopper using $30 \mathrm{~mL}$ hexane as extraction solvent.

The separating funnel was shaken vigorously after 3 minutes, the organic layer was allowed to visibly phase separate from the aqueous solution. The organic layer was collected into a different glass bottle. The extraction process was carried out in triplicates. Residues of water were expelled from the organic layer by passing extraction solvent through the separating funnels containing anhydrous sodium sulphate. Extracts were concentrated with rotary evaporators and water bath preset at $85^{\circ} \mathrm{C}$. Concentrated extracts was transferred to a preweighed sample bottle and evaporated to dryness.

\section{Interpolation of Bio Concentration Factor}

The bio-concentration factor was calculated by adapting the method described by (McCarty, 1986). The Bio-Concentration Factor (BCF) is the proportion of a particular chemical in tissue to its water concentration see equation 1 below. We took notice that BCF is relevant only for accumulation from water; wherein to compare among BCFs it is important to establish that water is the only route of uptake. Contrary to The Bioaccumulation Factor (BAF) which is generally computed as the proportion between the toxicant concentrations in tissue and multiple external sources (e.g., sediment, water and diet) and is useful in determining the tendency of hydrophobic compounds to accumulate in tissue. A seldom used term, dietary accumulation, is used to determine the proportion between the concentration of a contaminant in an organism and food:

$B C F$ with free PAHs in water $=$ Tissue $/($ Water free $)$

$\mathrm{BCF}$, (bio-concentration factor with free $\mathrm{PAH}$ in water $)=[$ Tissue $] /[$ Water free $]$

$\mathrm{BCF}$ is $\mathrm{BCF}$ predicted. For example the equation from [19]; = $0.046 \mathrm{~K}_{\mathrm{Ow}}$.

Total BCF of PAHs tissue load was calculated by summation of mean BCF of individual PAHs see Equation 2 below:

$$
\sum M B C F=T B C F T L
$$

Where:

$M B C F=$ Mean bio-concentration factor

$T B C F T L B=$ Total bio-concentration factor of tissue load 
The percentage Polycyclic Aromatic Hydrocarbons (PAHs) concentration in fish sample was calculated using equation 3 :

$$
\begin{aligned}
& \text { percentage PAHs concentration } \\
& =M B C F / T B C F T L \times 100 / 1
\end{aligned}
$$

Where:

$M B C F=$ Mean bio-concentration factor

$T B C F T L=$ Total bio-concentration factor of PAHs tissue load

\section{Statistical Analysis}

Investigations were carried out in triplicate and data are presented as mean \pm standard deviation using descriptive statistics. One way analysis of variance was used to compare mean difference among samples. Significance was accepted at $\mathrm{p}<0.05$.

\section{Results and Discussions}

Many studies have shown that marine organism's bio-accumulate PAHs from the environmental media. It is not so much a query or contemplation of whether an aquatic animal will bio-accumulate PAHs, instead, what quantity of these PAHs are bio-accumulated. This and other questions are concern for assessment of human health and safety. Since human beings live by consuming this contaminated resources as food. Considering the concentration of PAHs in environmental media, controlling the bioavailability of PAHs interval which the organism enduring the contaminant and the physiology of the organism to contest with PAHs Body Load, are all tune of aquatic pollution and degeneration. Bio-concentration patterns of PAHs in marine organisms are diverse in many factors. These include, but not limited to, exposure to pollutrd media, uptake rate of contaminated feeds stock, metabolic capability, age, lipid content and feeding strategy and habit (Adams, 1987; Meador et al., 1995; Roesijadi et al., 1978; Schrap and Opperhuizen, 1990; Varanasi et al., 1985). These factors are considered whenever accumulations of PAHs are compared. Because biotransformation of pollutants is one of the more important processes of evaluating metabolic capacity and inclination pattern of parent compounds included in many studies of PAHs bioaccumulation to assess total PAHs uptake accurately (Bruner et al., 1994).

In this investigation, 6 different fresh fish species that are customarily consumed as food by the residents of Eket community in Akwa Ibom State Nigeria, were randomly selected for screening of PAHs levels. This help established the extent of residual PAHs accumulation in aquatic animal model. Twelve (12) water samples were collected from Qua Ibeo River at 1 $\mathrm{km}$ apart. The screening was carried out using Agilent gas chromatography tandem mass spectroscopy. Upon investigation, the total mean concentration of individual toxicant in water and in fish was determination and reported in triplicate. The bio-concentration factor of the fishes was extrapolated by adapting the method of McCarty (1986) see equation 1.

The Bio-Concentration Factor (BCF) is the proportion of the tissue absorption of a particular substance to its water concentration. It was kept in perspective that the $\mathrm{BCF}$ is relevant only to the extent of accumulation from water; to compare among BCFs, it is important to establish that water is the only route of uptake. At equilibrium, the BCF generally increases with increasing chemical hydrophobicity because of the increased fugacity or tendency of the chemical to partition into the animal's lipid rather than stay in solution (Bruner et al., 1994; De Mora et al., 2004). The results obtained as mean concentration for toxicants body residues varies from species considerably. For example, Atlantic Crocker (Micropogonias undulates) showed naphthalene $10.370 \pm 0.302$ ppm, 2methylnaphthalene $10.160 \pm 0.112 \mathrm{ppm}$, acenaphthylene $10.170 \pm 0.151 \mathrm{ppm}$, acenaphthene $10.403 \pm 0.431 \mathrm{ppm}$, fluorene $12.707 \pm 4.593 \mathrm{ppm}$, phenanthrene $10.360 \pm 0.355$ ppm, anthracene $9.443 \pm 0.551 \mathrm{ppm}$, fluoranthene $16.416 \pm 3.787 \mathrm{ppm}$, pyrene $13.873 \pm 3.639 \mathrm{ppm}$, benzo (a) anthracene $10.240 \pm 0.832 \mathrm{ppm}$, triphenylene $10.216 \pm 0.120 \mathrm{ppm}$, benzo (e) pyrene $15.616 \pm 4.779 \mathrm{ppm}$, benzo (a) pyrene $16.200 \pm 5.232 \mathrm{ppm}$, Indeno (1, 2, 3, cd) pyrene $17.670 \pm 3.836 \mathrm{ppm}$, Benzo $(\mathrm{g}, \mathrm{h}, \mathrm{i})$ perylene $14.126 \pm 4.564$ ppm, dibenzo $(\mathrm{a}, \mathrm{h})$ anthracene $16.076 \pm 5.168 \mathrm{ppm}$ and 000053-70-3-benzo(e) pyrene $13.590 \pm 5.477 \mathrm{ppm}$ respectively Table 1-6.

Several researchers have noticed that PAHs concentrations in marine organisms appear to show seasonal variation, attributable to a number of factors (Atuanya and Nwogu, 2013). What customary with contaminants is that PAHs bio-accumulation in some tissues is higher, with larger proportions concentrated in the liver of vertebrates and the hepato-pancreas of invertebrates Nyarko et al. (2001). General, it's been observed that tissues rich in lipid preferentially bioaccumulate parent PAHs because of their strong hydrophobic nature (Umeh, 2009). Meanwhile, the total mean concentration of the individual contaminants or toxicants in water column was determined Table 1-6.

As exemplified in atlantic crocker (Micropogonias undulates). Results revealed 23.302 $\pm 0.114 \mathrm{ppm}$ for Naphthalene, 28.225 \pm 0.231 ppm 2-Methylnaphthalene, $16.564 \pm 0.220$ ppm Acenaphthylene, $27.585 \pm 1.210 \mathrm{ppm}$ Acenaphthene, 27.239 $\pm 0.123 \quad \mathrm{ppm}$ Fluorene, $28.421 \pm 2.100$ ppm Phenanthrene, 28.256 \pm 0.221 ppm Anthracene, $27.481 \pm 0.401 \quad$ ppm Fluoranthene, 28.201 \pm 1.091 ppm Pyrene, 26.264 \pm 0.220 ppm Benzo (a) 
anthracene, $\quad 29.077 \pm 0.329 \quad \mathrm{ppm} \quad$ Triphenylene, $27.594 \pm 0.211$ ppm Benzo (e) pyrene, 13.873 \pm 0.111 ppm Benzo (a) pyrene, 13.774 $\pm 0.213 \mathrm{ppm}$ Indeno (1, 2, 3, cd) pyrene, $28.383 \pm 0.210 \mathrm{ppm} \operatorname{Benzo}(\mathrm{g}, \mathrm{h}, \mathrm{i})$ perylene, $28.302 \pm 0.101 \mathrm{ppm}$ Dibenzo $(\mathrm{a}, \mathrm{h})$ anthracene and $27.828 \pm 0.171 \mathrm{ppm}$ for 000053-70-3-benzo(e) pyrene differently.

Accumulation may be a function of $\mathrm{PAH}$ hydrophobicity, but time of exposure and metabolic capacity must be considered. Several studies have shown rapid attainment of steady-state BCFs in marine organisms exposed to PAHs in water. For example, similar values $(\mathrm{BCFs} \cong 50)$ were calculated for Mytilus edulis after $4 \mathrm{~h}$ of exposure to labeled naphthalene and after 4 weeks exposure to unlabeled naphthalene, indicating rapid equilibration of exposure concentrations (Widdows et al., 1983). The determination of BCFs in field-collected animals is uncommon, possibly because it is difficult to assure water-only exposure and accurately determine temporally variable concentrations. In this study, the bio-concentration for all the models were quantified. Results showed variable bioconcentration of toxicants in fish as shown in Table 1-6.

Table 1. Mean concentration of PAHs bio-accumulated in Atlantic Crocker (Micropogonias undulates)

\begin{tabular}{lllll}
$\begin{array}{l}\text { Polycyclic aromatic hydrocarbons } \\
\text { (PAHs) }\end{array}$ & $\begin{array}{l}\text { Mean conc. of } \\
\text { contaminant in } \\
\text { fish (ppm) }\end{array}$ & $\begin{array}{l}\text { Mean conc. of } \\
\text { contaminant in } \\
\text { water (ppm) }\end{array}$ & $\begin{array}{l}\text { Mean Bio- } \\
\text { Concentration } \\
\text { factor (MBCF) }\end{array}$ & $\begin{array}{l}\text { Percentage } \\
\text { PAHs conc. (\%) }\end{array}$ \\
\hline Naphthalene & $10.370 \pm 0.302$ & $23.302 \pm 0.114$ & $0.4450 \pm 2.649$ & 4.52 \\
2-Methylnaphthalene & $10.160 \pm 0.112$ & $28.225 \pm 0.231$ & $0.3599 \pm 0.485$ & 3.65 \\
Acenaphthylene & $10.170 \pm 0.151$ & $16.564 \pm 0.220$ & $0.6139 \pm 0.686$ & 6.23 \\
Acenaphthene & $10.403 \pm 0.431$ & $27.585 \pm 1.210$ & $0.3771 \pm 0.356$ & 3.83 \\
Fluorene & $12.707 \pm 4.593$ & $27.239 \pm 0.123$ & $0.4665 \pm 37.34$ & 4.74 \\
Phenanthrene & $10.360 \pm 0.355$ & $28.421 \pm 2.100$ & $0.3666 \pm 0.169$ & 3.72 \\
Anthracene & $9.443 \pm 0.551$ & $28.256 \pm 0.221$ & $0.3341 \pm 2.493$ & 3.39 \\
Fluoranthene & $16.416 \pm 3.787$ & $27.481 \pm 0.401$ & $0.5974 \pm 9.444$ & 6.07 \\
Pyrene & $13.873 \pm 3.639$ & $28.201 \pm 1.091$ & $0.4919 \pm 3.335$ & 5 \\
Benzo (a) anthracene & $10.240 \pm 0.832$ & $26.264 \pm 0.220$ & $0.3899 \pm 3.782$ & 3.96 \\
Triphenylene & $10.216 \pm 0.120$ & $29.077 \pm 0.329$ & $0.3513 \pm 0.365$ & 3.57 \\
Benzo (e) pyrene & $15.616 \pm 4.779$ & $27.594 \pm 0.211$ & $0.5659 \pm 22.65$ & 5.75 \\
Benzo (a) pyrene & $16.200 \pm 5.232$ & $13.873 \pm 0.111$ & $1.1677 \pm 47.13$ & 11.86 \\
Indeno (1, 2, 3, cd) pyrene & $17.670 \pm 3.836$ & $13.774 \pm 0.213$ & $1.2829 \pm 18.01$ & 13.03 \\
Benzo (g, h, i) perylene & $14.126 \pm 4.564$ & $28.383 \pm 0.210$ & $0.9769 \pm 21.73$ & 9.92 \\
Dibenzo (a,h) anthracene & $16.076 \pm 5.168$ & $28.302 \pm 0.101$ & $0.5681 \pm 51.17$ & 5.79 \\
000053-70-3-benzo (e) pyrene & $13.590 \pm 5.477$ & $27.828 \pm 0.171$ & $0.4884 \pm 32.03$ & 4.96 \\
Total BCF of PAHs tissue load & & & $9.8439 \pm 6.569$ & $100 \%$ \\
\hline
\end{tabular}

Table 2. Mean concentration of PAHs bio-accumulated in Tilpia (Oreochromis niloticus)

\begin{tabular}{lllll}
\hline & $\begin{array}{l}\text { Mean conc. of } \\
\text { contaminant in } \\
\text { fish (ppm) }\end{array}$ & $\begin{array}{l}\text { Mean conc. of } \\
\text { contaminant in } \\
\text { water (ppm) }\end{array}$ & $\begin{array}{l}\text { Mean BIO } \\
\text { Concentration } \\
\text { Factor (BCF) }\end{array}$ & $\begin{array}{l}\text { Percentage } \\
\text { PAHs conc. (\%) }\end{array}$ \\
\hline Naphthalene & $13.573 \pm 4.134$ & $23.302 \pm 0.114$ & $0.5825 \pm 36.263$ & 5.94 \\
2-Methylnaphthalene & $13.140 \pm 5.161$ & $28.225 \pm 0.231$ & $0.4655 \pm 22.342$ & 4.76 \\
Acenaphthylene & $13.767 \pm 4.794$ & $16.564 \pm 0.22$ & $0.8311 \pm 3.9215$ & 8.49 \\
Acenaphthene & $13.727 \pm 4.745$ & $27.585 \pm 1.210$ & $0.4976 \pm 3.9215$ & 5.08 \\
Fluorene & $18.700 \pm 0.572$ & $27.239 \pm 0.123$ & $0.6865 \pm 4.6504$ & 7.02 \\
Phenanthrene & $16.590 \pm 5.088$ & $28.421 \pm 2.100$ & $0.5837 \pm 2.4229$ & 5.96 \\
Anthracene & $16.616 \pm 4.958$ & $28.256 \pm 0.221$ & $0.5881 \pm 22.434$ & 6 \\
Fluoranthene & $13.970 \pm 4.604$ & $27.481 \pm 0.401$ & $0.5083 \pm 11.481$ & 5.19 \\
Pyrene & $13.426 \pm 5.191$ & $28.201 \pm 1.091$ & $0.4761 \pm 4.7580$ & 4.84 \\
Benzo (a) anthracene & $13.280 \pm 5.076$ & $26.264 \pm 0.220$ & $0.5056 \pm 23.072$ & 5.17 \\
Triphenylene & $13.840 \pm 5.018$ & $29.079 \pm 0.329$ & $0.4749 \pm 15.428$ & 4.84 \\
Benzo (e) pyrene & $16.513 \pm 5.190$ & $27.594 \pm 0.211$ & $0.5876 \pm 24.597$ & 6.01 \\
Benzo (a) pyrene & $16.073 \pm 5.069$ & $13.873 \pm 0.111$ & $1.1586 \pm 45.667$ & 11.84 \\
Indeno (1, 2, 3, cd) pyrene & $12.586 \pm 5.105$ & $13.774 \pm 0.213$ & $0.9072 \pm 23.967$ & 9.27 \\
Benzo (g,h,i) perylene & $13.473 \pm 4.876$ & $28.382 \pm 0.210$ & $0.4747 \pm 22.892$ & 4.85 \\
Dibenzo (a,h) anthracene & $13.350 \pm 5.009$ & $28.302 \pm 0.101$ & $0.4717 \pm 49.594$ & 4.82 \\
000053-70-3-benzo (e) pyrene & $13.263 \pm 5.245$ & $27.828 \pm 0.171$ & $0.4766 \pm 30.673$ & 4.87 \\
Total BCF of PAHs tissue load & & & $9.7790 \pm 12.305$ & $100 \%$ \\
\hline
\end{tabular}


Table 3. Mean concentration of PAHs bio-accumulated in Yellow tail (Seriola lalandi)

\begin{tabular}{lllll}
\hline & $\begin{array}{l}\text { Mean conc. of } \\
\text { contaminant in } \\
\text { fish (ppm) }\end{array}$ & $\begin{array}{l}\text { Mean conc. of } \\
\text { contaminant in } \\
\text { water (ppm) }\end{array}$ & $\begin{array}{l}\text { Mean Bio- } \\
\text { Concentration } \\
\text { Factor (BCF) }\end{array}$ & $\begin{array}{l}\text { Percentage } \\
\text { PAHs conc. (\%) }\end{array}$ \\
\hline Naphthalene & $18.6933 \pm 0.583$ & $23.3017 \pm 0.114$ & $0.8022 \pm 5.114$ & 6.11 \\
2-Methylnaphthalene & $16.1300 \pm 5.232$ & $28.2250 \pm 0.231$ & $0.5714 \pm 22.64$ & 4.35 \\
Acenaphthylene & $16.1100 \pm 5.274$ & $16.5644 \pm 0.220$ & $0.9726 \pm 23.97$ & 7.41 \\
Acenaphthene & $16.5500 \pm 5.570$ & $27.5853 \pm 1.210$ & $0.5999 \pm 4.603$ & 4.57 \\
Fluorene & $19.4967 \pm 0.412$ & $27.2386 \pm 0.123$ & $0.7068 \pm 3.349$ & 5.39 \\
Phenanthrene & $19.3867 \pm 0.398$ & $28.4211 \pm 2.100$ & $0.6820 \pm 0.189$ & 5.2 \\
Anthracene & $18.553 \pm 1.355$ & $28.2558 \pm 0.221$ & $0.6566 \pm 6.131$ & 5 \\
Fluoranthene & $18.890 \pm 0.795$ & $27.4806 \pm 0.401$ & $0.6874 \pm 1.983$ & 5.24 \\
Pyrene & $16.086 \pm 5.219$ & $28.2011 \pm 1.091$ & $0.5700 \pm 4.784$ & 4.34 \\
Benzo (a) anthracene & $16.066 \pm 5.202$ & $26.2642 \pm 0.220$ & $0.6117 \pm 23.65$ & 4.66 \\
Triphenylene & $19.066 \pm 1.050$ & $29.0786 \pm 0.329$ & $0.6556 \pm 3.191$ & 5 \\
Benzo (e) pyrene & $19.100 \pm 0.078$ & $27.5942 \pm 0.211$ & $0.6922 \pm 0.369$ & 5.27 \\
Benzo (a) pyrene & $19.090 \pm 0.101$ & $13.8728 \pm 0.111$ & $1.4344 \pm 0.909$ & 10.94 \\
Indeno (1,2,3, cd) pyrene & $19.123 \pm 0.624$ & $13.7744 \pm 0.213$ & $1.3883 \pm 2.929$ & 10.58 \\
Benzo (g,h,i) perylene & $19.590 \pm 0.375$ & $28.3825 \pm 0.210$ & $0.6902 \pm 9.277$ & 5.26 \\
Dibenzo (a,h) anthracene & $20.203 \pm 0.937$ & $28.3017 \pm 0.101$ & $0.7138 \pm 9.277$ & 5.44 \\
000053-70-3-benzo (e) pyrene & $18.796 \pm 0.571$ & $27.8281 \pm 0.171$ & $0.6754 \pm 3.339$ & 5.14 \\
Total BCF of PAHs tissue load & & & $13.111 \pm 1.247$ & $100 \%$ \\
\hline
\end{tabular}

Table 4 mean concentration of PAHs bio-accumulated in Barracuda Fish (Sphyraena barracuda)

\begin{tabular}{lllll}
\hline & $\begin{array}{l}\text { Mean conc. of } \\
\text { Polycyclic aromatic hydrocarbons }\end{array}$ & $\begin{array}{l}\text { Mean conc. of } \\
\text { Contaminant in } \\
\text { (PAHs) }\end{array}$ & $\begin{array}{l}\text { Mean Bio- } \\
\text { Concentration }\end{array}$ & $\begin{array}{l}\text { Percentage } \\
\text { PAHs conc. (\%) }\end{array}$ \\
\hline Naphthalene & $9.360 \pm 0.795$ & $23.302 \pm 0.114$ & $0.402 \pm 6.974$ & 5.86 \\
2-Methylnaphthalene & $9.550 \pm 0.446$ & $28.225 \pm 0.231$ & $0.339 \pm 1.930$ & 4.94 \\
Acenaphthylene & $9.4300 \pm 0.578$ & $16.564 \pm 0.220$ & $0.569 \pm 2.627$ & 8.3 \\
Acenaphthene & $9.806 \pm 0.596$ & $27.585 \pm 1.210$ & $0.355 \pm 0.492$ & 5.18 \\
Fluorene & $8.777 \pm 1.154$ & $27.239 \pm 0.123$ & $0.322 \pm 9.382$ & 4.71 \\
Phenanthrene & $8.726 \pm 0.903$ & $28.421 \pm 2.100$ & $0.307 \pm 0.43$ & 4.78 \\
Anthracene & $10.086 \pm 0.030$ & $28.256 \pm 0.221$ & $0.357 \pm 0.135$ & 5.2 \\
Fluoranthene & $9.766 \pm 0.516$ & $27.481 \pm 0.401$ & $0.355 \pm 1.286$ & 5.8 \\
Pyrene & $9.753 \pm 0.575$ & $28.201 \pm 1.091$ & $0.346 \pm 0.527$ & 5.04 \\
Benzo (a) anthracene & $9.913 \pm 0.375$ & $26.264 \pm 0.220$ & $0.377 \pm 1.705$ & 5.5 \\
Triphenylene & $9.826 \pm 0.422$ & $29.077 \pm 0.329$ & $0.337 \pm 1.283$ & 4.91 \\
Benzo (e) pyrene & $9.960 \pm 0.338$ & $27.594 \pm 0.211$ & $0.361 \pm 1.602$ & 5.27 \\
Benzo (a) pyrene & $9.473 \pm 0.677$ & $13.873 \pm 0.111$ & $0.683 \pm 6.099$ & 9.97 \\
Indeno (1, 2, 3, cd) pyrene & $9.490 \pm 0.364$ & $13.774 \pm 0.213$ & $0.689 \pm 1.709$ & 10.05 \\
Benzo (g,h,i) perylene & $9.800 \pm 0.616$ & $28.383 \pm 0.210$ & $0.345 \pm 2.933$ & 5.03 \\
Dibenzo (a,h) anthracene & $10.093 \pm 0.565$ & $28.302 \pm 0.101$ & $0.357 \pm 5.594$ & 5.21 \\
000053-70-3-benzo (e) pyrene & $9.676 \pm 0.480$ & $27.828 \pm 0.171$ & $0.348 \pm 2.807$ & 5.08 \\
Total BCF of PAHs tissue load & & & $6.853 \pm 7.937$ & $100 \%$ \\
\hline
\end{tabular}

One study have reported variable BCFs in the range of $7 \times 10^{3}$ to $3 \times 10^{4}$ in an urban area and $1 \times 10^{1}$ to $5 \times 10^{1}$ in an oil refinery area for mussels (Mytilus edulis planulatus) from southeast Australia Murray et al. (1991). Interestingly, the BCFs for benzo[b] fluoranthene, benzo [k] fluoranthene and benzo[a]pyrene were 10-44 times higher in models collected from the oil refinery sites versus those in animals collected from the urban sites. Bioconcentration factors for fish are very difficult to calculate because extensive biotransformation results in the rapid disappearance of parent PAHs from tissues. Measurement of tissue burdens of parent compounds normalized to water concentrations will severely underestimate the BCF. As described earlier, alternate measurements of $\mathrm{PAH}$ accumulation may be more useful in assessing exposure. In the same vain, results in Table 3 and 4 showed the similar trend. As mean bio-concentration of toxicants varies in fish tissues. 
Table 5. Mean concentration of PAHs bio-accumulated in Cat Fish (Clarias gariepinus)

\begin{tabular}{lllll}
\hline $\begin{array}{l}\text { Polycyclic aromatic hydrocarbons } \\
\text { (PAHs) }\end{array}$ & $\begin{array}{l}\text { Mean conc. of } \\
\text { Contaminant in } \\
\text { fish (ppm) }\end{array}$ & $\begin{array}{l}\text { Mean conc. of } \\
\text { Contaminant in } \\
\text { water (ppm) }\end{array}$ & $\begin{array}{l}\text { Mean Bio- } \\
\text { Concentration } \\
\text { Factor (BCF) }\end{array}$ & $\begin{array}{l}\text { Percentage } \\
\text { PAHs conc. (\%) }\end{array}$ \\
\hline Naphthalene & $10.517 \pm 0.453$ & $23.302 \pm 0.114$ & $0.451 \pm 3.974$ & 6.18 \\
2-Methylnaphthalene & $10.476 \pm 0.551$ & $28.225 \pm 0.231$ & $0.371 \pm 2.385$ & 5.08 \\
Acenaphthylene & $10.170 \pm 0.500$ & $16.564 \pm 0.220$ & $0.613 \pm 2.272$ & 8.4 \\
Acenaphthene & $10.097 \pm 0.023$ & $27.585 \pm 1.210$ & $0.366 \pm 0.019$ & 5.01 \\
Fluorene & $10.146 \pm 0.115$ & $27.239 \pm 0.123$ & $0.372 \pm 0.934$ & 5.09 \\
Phenanthrene & $10.400 \pm 0.294$ & $28.421 \pm 2.100$ & $0.366 \pm 0.140$ & 5.04 \\
Anthracene & $10.373 \pm 0.458$ & $28.256 \pm 0.221$ & $0.367 \pm 2.072$ & 5.03 \\
Fluoranthene & $11.646 \pm 0.803$ & $27.481 \pm 0.401$ & $0.423 \pm 2.002$ & 5.79 \\
Pyrene & $10.360 \pm 0.312$ & $28.201 \pm 1.091$ & $0.367 \pm 0.286$ & 5.03 \\
Benzo (a) anthracene & $10.613 \pm 0.512$ & $26.264 \pm 0.220$ & $0.404 \pm 2.327$ & 5.54 \\
Triphenylene & $10.206 \pm 0.215$ & $29.077 \pm 0.329$ & $0.351 \pm 0.653$ & 4.81 \\
Benzo (e) pyrene & $10.323 \pm 0.195$ & $27.594 \pm 0.211$ & $0.374 \pm 0.924$ & 5.12 \\
Benzo (a) pyrene & $9.436 \pm 1.411$ & $13.873 \pm 0.111$ & $0.680 \pm 12.711$ & 9.32 \\
Indeno (1,2,3, cd) pyrene & $9.656 \pm 1.064$ & $13.774 \pm 0.213$ & $0.701 \pm 4.995$ & 9.61 \\
Benzo (g,h,i) perylene & $10.133 \pm 1.021$ & $28.383 \pm 0.210$ & $0.357 \pm 4.862$ & 4.89 \\
Dibenzo (a,h) anthracene & $10.336 \pm 0.275$ & $28.302 \pm 0.101$ & $0.365 \pm 2.722$ & 5 \\
000053-70-3-benzo (e) pyrene & $10.193 \pm 0.020$ & $27.828 \pm 0.171$ & $0.366 \pm 0.117$ & 5.01 \\
Total BCF of PAHs tissue load & & & $7.298 \pm 4.529$ & $100 \%$ \\
\hline
\end{tabular}

Table 6. Mean concentration of PAHs bio-accumulated in African Red snipper (Lutjanus agennes) fish

\begin{tabular}{lllll}
\hline & $\begin{array}{l}\text { Mean conc. of } \\
\text { Contaminant in } \\
\text { fish (ppm) }\end{array}$ & $\begin{array}{l}\text { Mean conc. of } \\
\text { Contaminant in } \\
\text { water (ppm) }\end{array}$ & $\begin{array}{l}\text { Mean Bio- } \\
\text { Concentration } \\
\text { Factor (BCF) }\end{array}$ & $\begin{array}{l}\text { Percentage } \\
\text { PAHs conc. (\%) }\end{array}$ \\
\hline Naphthalene & $10.517 \pm 0.453$ & $23.302 \pm 0.114$ & $0.451 \pm 3.974$ & 6.18 \\
2-Methylnaphthalene & $10.476 \pm 0.551$ & $28.225 \pm 0.231$ & $0.371 \pm 2.385$ & 5.08 \\
Acenaphthylene & $10.170 \pm 0.500$ & $16.564 \pm 0.220$ & $0.613 \pm 2.272$ & 8.4 \\
Acenaphthene & $10.097 \pm 0.023$ & $27.585 \pm 1.210$ & $0.366 \pm 0.019$ & 5.01 \\
Fluorene & $10.146 \pm 0.115$ & $27.239 \pm 0.123$ & $0.372 \pm 0.934$ & 5.09 \\
Phenanthrene & $10.400 \pm 0.294$ & $28.421 \pm 2.100$ & $0.366 \pm 0.140$ & 5.04 \\
Anthracene & $10.373 \pm 0.458$ & $28.256 \pm 0.221$ & $0.367 \pm 2.072$ & 5.03 \\
Fluoranthene & $11.646 \pm 0.803$ & $27.481 \pm 0.401$ & $0.423 \pm 2.002$ & 5.79 \\
Pyrene & $10.360 \pm 0.312$ & $28.201 \pm 1.091$ & $0.367 \pm 0.286$ & 5.03 \\
Benzo (a) anthracene & $10.613 \pm 0.512$ & $26.264 \pm 0.220$ & $0.404 \pm 2.327$ & 5.54 \\
Triphenylene & $10.206 \pm 0.215$ & $29.077 \pm 0.329$ & $0.351 \pm 0.653$ & 4.81 \\
Benzo (e) pyrene & $10.323 \pm 0.195$ & $27.594 \pm 0.211$ & $0.374 \pm 0.924$ & 5.12 \\
Benzo (a) pyrene & $9.436 \pm 1.411$ & $13.873 \pm 0.111$ & $0.680 \pm 12.711$ & 9.32 \\
Indeno (1,2,3, cd) pyrene & $9.656 \pm 1.064$ & $13.774 \pm 0.213$ & $0.701 \pm 4.995$ & 9.61 \\
Benzo (g,h,i) perylene & $10.133 \pm 1.021$ & $28.383 \pm 0.210$ & $0.357 \pm 4.862$ & 4.89 \\
Dibenzo (a,h) anthracene & $10.336 \pm 0.275$ & $28.302 \pm 0.101$ & $0.365 \pm 2.722$ & 5 \\
000053-70-3-benzo (e) pyrene & $10.193 \pm 0.020$ & $27.828 \pm 0.171$ & $0.366 \pm 0.117$ & 5.01 \\
Total BCF of PAHs tissue load & & & $7.298 \pm 4.529$ & $100 \%$ \\
\hline
\end{tabular}

The mean bio-concentration of Toxicants body residues for Tilpia (Oreochromis niloticus) was calculated, results revealed naphthalene $0.5825 \pm 36.263,2$-methylnaphthalene $0.4655 \pm 22.342$, acenaphthylene $\quad 0.8311 \pm 3.9215$, acenaphthene $0.4976 \pm 3.9215$, Fluorene $0.6865 \pm 4.6504$, phenanthrene $0.5837 \pm 2.4229$, Anthracene $0.5881 \pm 22.434$, fluoranthene $0.5083 \pm 11.481$, pyrene $0.4761 \pm 4.7580$, Benzo (a) anthracene $0.5056 \pm 23.072$, triphenylene $0.4749 \pm 15.428$, benzo (e) pyrene $0.5876 \pm 24.597$, Benzo (a) pyrene $1.1586 \pm 45.667$, Indeno $(1,2,3$, cd) pyrene $0.9072 \pm 23.967$, benzo $(\mathrm{g}, \mathrm{h}, \mathrm{i})$ perylene $0.4747 \pm 22.892$, dibenzo $(\mathrm{a}, \mathrm{h})$ anthracene $0.4717 \pm 49.594$ and 000053-70-3-benzo(e) pyrene $0.4766 \pm 30.673$ respectively Table 2 and 3 .
Correlations between PAHs in the environmental matrixes and in tissues load of contaminants, these can be useful in assessment of exposure to pollutants (Dhananjayan and Muralidharan, 2012). One study found strong gradient of PAH concentration in sediment and mussel (Mytilus edulis and Modiolus modiolus) tissue up to several kilometers away from a ferro-alloy smelter Boese et al. (1990).

Both oysters (Crassostrea virginica) and clams (Rangia cuneata) sampled in the fall contained about 2-3 times more aromatic hydrocarbons than those sampled at the same sites during the spring season (Bender et al., 1986), leading to the hypothesis that differences resulted 
from the spawning cycle. Bio-Concentration and Bioaccumulation Factors (BCFs and BAFs) are useful ratios that can indicate steady-state exposure and expected tissue burdens are based on environmental concentrations. Table 4 present the result of toxicants body residues of yellow tail fish (Seriola lalandi). So far, the elucidation of BCF showed that Naphthalene $0.8022 \pm 5.114,2$ Methylnaphthalene $\quad 0.5714 \pm 22.64$, Acenaphthylene $0.9726 \pm 23.97$, Acenaphthene $0.5999 \pm 4.603$, Fluorene $0.7068 \pm 3.349$, Phenanthrene, $0.6820 \pm 0.189$, Anthracene $0.6566 \pm 6.131$, Fluoranthene $0.6874 \pm 1.983$, Pyrene $0.5700 \pm 4.784$, Benzo (a) anthracene 0.6117 \pm 23.65 , Triphenylene $0.6556 \pm 3.191$, Benzo (e) pyrene $0.6922 \pm 0.369$, Benzo (a) pyrene $1.4344 \pm 0.909$, Indeno (1, 2 , 3,cd) pyrene $1.3883 \pm 2.929$, Benzo $(\mathrm{g}, \mathrm{h}, \mathrm{i})$ perylene $0.6902 \pm 9.277$, Dibenzo (a,h) anthracene 0.7138 \pm 9.277 and 000053-70-3-benzo(e) pyrene 0.6754 \pm 3.339 .

Some researchers have noticed a pattern of differential accumulation which differ over major PAH groups (for example, compounds containing 2 through 6 aromatic rings). Varanasi et al. (1985; Isaac and Labunmi, 2010), reported that 2, 3 and 5-ring PAHs were poorly taken up by amphipods (Eohaustorius washingtonianus and Rhepoxynius abronius) and a clam (Macoma nasuta) when compared to 4-ring compounds Rose et al. (2012). This make us extrapolates the total mean PAHs body load and percentage body load. The contaminant body load was extrapolated by summation of individual PAHs mean concentration. Following this, results shows African Red snipper (Lutjanus agennes) have $20.822 \pm 0.6132$ body load of contaminants as the highest, followed in decreasing order by Yellow tail (Seriola lalandi) 13.111 \pm 1.247 , Atlantic Crocker (Micropogonias undulates) 9.8439 \pm 6.569 , Tilpia (Oreochromis niloticus) 9.7790 \pm 12.305 , Cat Fish (Clarias gariepinus) 7.298 \pm 4.529 and Barracuda (Sphyraena barracuda) $6.853 \pm 7.937$ respectively. The percentage PAHs concentration in samples was also determined, for instance, African red snapper have $10.9 \%$ Indeno $(1,2,3, \mathrm{~cd})$ pyrene, Yellow tail $10.94 \%$ Benzo (a) pyrene, Barracuda 10.05\% Indeno (1,2,3,cd) pyrene, Atlantic Croker $13.03 \%$ Indeno $(1,2,3, \mathrm{~cd})$ pyrene, Catfish 9.61\% Indeno $(1,2,3$, cd) pyrene and Tilapia (Oreochromis niloticus) 11.84\% Indeno (1, 2, 3, cd) pyrene Table 5 and 6 respectively.

The amount of PAHs in a sample is useful as an indicator of residual petroleum contamination at the site and toxicants body load in sample pattern may have resulted from the volatility of the 2 and 3-ring compounds, which may be released directly without metabolism from the organism, slower uptake kinetics of the more hydrophobic PAHs and the reduced uptake of the 5 and 6-ring compounds, which are suspected of being more tightly bound to organic carbon and hence less available to organisms as exemplify in various individual toxicant. These may affect people, animals and plants over time if exposure persist.

\section{Conclusion}

The observed levels of PAHs in fish species indicates that Qua Iboe River in Eket community of Akwa Ibom state is contaminated with PAHs. Therefore, Eket community is at risk of contracting cancer and other associated hormonal diseases as a result of their persistence exposure to/and consumption of the fishes. It is believe that other fish species do bio-accumulate the toxicants and possibly, beyond permissible limit. However, periodic monitoring of the aquatic environment will give insight into the levels of PAHs in the water body. It is suggested that bioconcentration of PAHs know no boundary and that studies from each major aquatic environment are relevant. Future work on the subjects of uptake efficiency, the role of qualitative and quantitative differences in organic carbon in determining bioavailability, assumed environmental equilibrium, nutritional migration of compounds and metabolites, predictable bio-accumulation factors and the variability in toxico-kinetic parameters are functions of chemical hydrophobicity associated with environmental changes and physiological posture will enhance understanding of $\mathrm{PAH}$ bio-accumulation and elimination in marine organisms. These will ultimately give empirical evidence for impact and risk assessment of both aquatic population and public health and safety.

\section{Acknowledgment}

We would like to thank Mr. Paul Nwachukwu of the international energy center and research development, Port Harcourt, River state for an excellent knowledge for running the GC/MS analysis. We also thank Dr. J. Parkar Elijah for his generosity in running the statistical analysis and Mr. Christopher Akaka for supplying the ice park and vessels used to convey the water and fish samples to the analytical laboratory.

\section{Author's Contributions}

All authors contributed equally in this investigation.

\section{Ethics}

This investigation was carried out in compliance with the Nigerian Environmental protection right.

\section{References}

Adams, W.J., 1987. Bioavailability of Neutral Lipophilic Organic Chemicals Contained on Sediments: A Review. In: Fate and Effects of Sediment-Bound Chemicals in Aquatic Systems, Dickson, K.L., A.W. Maki and W.A. Brungs (Eds.), Pergamon Press, New York, pp: 219-244. 
Atuanya, E.I. and N.A. Nwogu, 2013. Evaluation of bacteriological and mercury level in cod (Gadus morhua) and saithe (Pollachius virens) stockfish sold in Benin City, Edo State, Nigeria. Int. J. Adv. Res., 1: 211-214.

Bender, M.E., P.O. DeFur and R.J. Huggett, 1986. Polynuclear aromatic hydrocarbon monitoring in estuaries utilizing: oysters, brackish water clams and sediments. Proceedings of the Oceans, Sept. 23-25, IEEE Xplore Press, pp: 791-796.

DOI: $10.1109 /$ OCEANS.1986.1160389

Boese, B.L., H.I.I. Lee, D.T. Specht,, R.C. Randall and M.H. Winsor, 1990. Comparison of aqueous and solid-phase uptake for hexachlorobenzene in the tellinid clam Macoma nasuta (Conrad): A mass balance approach. Environ. Toxicol. Chem., 9: 221-231. DOI: 10.1002/etc.5620090213

Bruner, K.A., S.W. Fisher and P.F. Landrum, 1994. The role of the zebra mussel, Dreissena polymorpha, in contaminant cycling: II. Zebra mussel contaminant accumulation from algae and suspended particles and transfer to the benthic invertebrate, Gammarus fasciatus. J. Great Lakes Res., 20: 735-750. DOI: 10.1016/S0380-1330(94)71191-6

De Mora, S., S.W. Fowler, E. Wyse and S. Azemard, 2004. Distribution of heavy metals in marine bivalves, fish and coastal sediments in the Gulf and Gulf of Oman. Mar. Pollut. Bull., 49: 410-424. DOI: 10.1016/j.marpolbul.2004.02.029

DeWitt, T.H., R.J. Ozretich, R.C. Swartz, J.O. Lamberson and D.W. Schults et al., 1992. The influence of organic matter quality on the toxicity and partitioning of sediment-associated fluoranthene. Environ. Toxicol. Chem., 11: 197-208.

DOI: $10.1002 /$ etc. 5620110209

Dhananjayan, V. and S. Muralidharan, 2012. Polycyclic aromatic hydrocarbons in various species of fishes from Mumbai Harbour, India and their dietary intake concentration to human. Int. J. Oceanography, 2012: 645178-645178. DOI: $10.1155 / 2012 / 645178$

Gobas, F.A.P.C., J.B. Wilcockson, R.W. Russell and G.D. Haffner, 1999. Mechanism of biomagnification in fish under laboratory and field conditions. Environ. Scientific Technol., 33: 133-141. DOI: $10.1021 / \mathrm{es} 980681 \mathrm{~m}$

Isaac, A.O. and L. Labunmi, 2010. Exposure level and bioaccumulation of polycyclic aromatic hydrocarbons (PAHs) in edible marine organisms. J. Environ. Indicators, 5: 69-88.

McCarty, L.S., 1986. The relationship between aquatic toxicity QSARS and bioconcentration for some organic chemicals. Environ. Toxicol. Chem., 5: 1071-1080. DOI: 10.1002/etc.5620051207
Meador, J.P., E. Casillas, C.A. Sloan and U. Varanasi, 1995. Comparative bioaccumulation of polycyclic aromatic hydrocarbons from sediment by two infaunal invertebrates. Marine Ecol. Prog. Ser., 123: 107-124. DOI: 10.3354/meps 123107

Murray, A.P., B.J. Richardson and C.F. Gibbs, 1991. Bioconcentration factors for petroleum hydrocarbons, PAHs, LABs and biogenic hydrocarbons in the blue mussel. Marine Pollut. Bull., 22: 595-603. DOI: 10.1016/0025-326X (91) 90247-P

NRC, 1991. Human Exposure Assessment for Airborne Pollutants: Advances and Opportunities. National Research Council, Washington, D.C., pp: 321.

NRC, 1992. Multiple Chemical Sensitivities: Addendum to Biologic Markers in Immunotoxicology. 1st Edn., National Research Council, ISBN-10: 0-309-59796-X, pp: 200.

Nyarko, E., B.O. Botwe and E. Klubi, 2001. Polycyclic Aromatic Hydrocarbon (PAHs) levels in two commercially important fish species from the Coastal Waters of Ghana and their carcinogenic health risks. West African J. Applied Ecol., 19: 53-66.

Roesijadi, G., J.W. Anderson and J.W. Blaylock, 1978. Uptake of hydrocarbons from marine sediments contaminated with Prudhoe Bay crude oil: influence of feeding type of test species and availability of polycyclic aromatic hydrocarbons. J. Fish Res. Board Can., 35: 608-614. DOI: 10.1139/f78-107

Rose, A., D. Ken, O. Kehinde and A. Babajide, 2012. Bioaccumulation of polycyclic aromatic hydrocarbons in fish and invertebrates of Lagos lagoon, Nigeria. J. Emerg. Trends Eng. Applied Sci., 3: 287-296.

Schrap, S.M. and A. Opperhuizen, 1990. Relationship between bioavailability and hydrophobicity: Reduction of the uptake of organic chemicals by fish due to the sorption on particles. Environ. Toxicol. Chem., 9: 715-724. DOI: 10.1002/etc.5620090604

Umeh, G.I., 2009. Impacts of petroleum hydrocarbons on fish communities of river Areba, Niger Delta, Southern Nigeria. Tropical Freshwater Biol., 18: 79-91.

Varanasi, U., W.L. Reichert, J.E. Stein, D.W. Brown and H.R. Sanborn, 1985. Bioavailability and biotransformation of aromatic hydrocarbons in benthic organisms exposed to sediment from an urban estuary. Environ. Sci. Technology 19: 836-841. DOI: 10.1021/es00139a012

Widdows, J., S. L. Moore, K. R. Clarke and P. Donkin, 1983. Uptake, tissue distribution and elimination of $\left[1-{ }^{14} \mathrm{C}\right]$ naphthalene in the mussel Mytilus edulis. Marine Biol., 176: 109-114. DOI: $10.1007 / \mathrm{BF} 00392727$ 